\title{
COMPARISON OF MEAT QUALITY RELATED CHEMICAL COMPOSITIONS OF WILD-CAPTURED AND CAGE-CULTURED COBIA
}

Jan-Lung Chuang

Department of Hospitality Management, Nan-Jeon Institute, Tainan, Taiwan, R.O.C.

Ruey-Tarng Lin

Department of Food Science, National Taiwan Ocean University, Keelung, Taiwan, R.O.C

Chyuan-Yuan Shiau

Department of Food Science, National Taiwan Ocean University, Keelung, Taiwan, R.O.C, cyshiau@mail.ntou.edu.tw

Follow this and additional works at: https://jmstt.ntou.edu.tw/journal

Part of the Aquaculture and Fisheries Commons

\section{Recommended Citation}

Chuang, Jan-Lung; Lin, Ruey-Tarng; and Shiau, Chyuan-Yuan (2010) "COMPARISON OF MEAT QUALITY RELATED CHEMICAL COMPOSITIONS OF WILD-CAPTURED AND CAGE-CULTURED COBIA," Journal of Marine Science and Technology. Vol. 18: Iss. 4, Article 14.

DOI: $10.51400 / 2709-6998.1920$

Available at: https://jmstt.ntou.edu.tw/journal/vol18/iss4/14

This Research Article is brought to you for free and open access by Journal of Marine Science and Technology. It has been accepted for inclusion in Journal of Marine Science and Technology by an authorized editor of Journal of Marine Science and Technology. 
COMPARISON OF MEAT QUALITY RELATED CHEMICAL COMPOSITIONS OF WILD-CAPTURED AND CAGE-CULTURED COBIA

\section{Acknowledgements}

This work was supported by a grant from Fisheries Administration, Council of Agriculture, Republic of China. 


\title{
COMPARISON OF MEAT QUALITY RELATED CHEMICAL COMPOSITIONS OF WILD-CAPTURED AND CAGE-CULTURED COBIA
}

\author{
Jan-Lung Chuang*, Ruey-Tarng Lin**, and Chyuan-Yuan Shiau**
}

Key words: cobia, chemical compositions, wide-captured, cagecultured.

\begin{abstract}
Nine wild-captured cobia (Rachycentron canadum) and the compatible number and size of cultured cobia from two cagecultured sites, namely Penghu (PH) and Pingtung (PT) Counties, were sampled for chemical analyses. The condition factor of wild cobia was significantly lower than those of cultured fish. The wild cobia had higher moisture content than that of the cultured one, while fat contents in both dorsal and ventral muscles of the former were significantly lower than those of the latter. There were no significant differences between cultured and wild cobia in protein and ash contents. The total free amino acids (FAAs) contents in cultured cobia from two different localities were higher than those of wild fish. Taurine was the most prominent FAA in wild cobia, while glycine was more prominent in cultured fish than in the wild one. Lysine contents were significantly the highest in both dorsal and ventral muscles in PH-cultured cobia. The contents of glutamic acid, glutamine, alanine, ornithine and proline in cultured cobia were higher than those in wild cobia. There was no significant difference between wild and cultured cobia in anserine content, while carnosine was detected only in wild cobia. Inosine monophosphate was the major component in ATP-related compounds in both wild and cultured cobia, but no significant difference in its levels between the wild and cultured groups was found. The contents of ammonia was higher in PH-cultured cobia than those in both PT-cultured and wild cobia, yet no significant difference in urea content of both $\mathrm{D}$ and $\mathrm{V}$ muscles among the three groups.
\end{abstract}

Paper submitted 09/05/08; revised 07/01/09; accepted 08/25/09. Author for correspondence: Chyuan-Yuan Shiau (e-mail: cyshiau@mail.ntou.edu.tw).

*Department of Hospitality Management, Nan-Jeon Institute, Tainan, Taiwan, R.O.C.

**Department of Food Science, National Taiwan Ocean University, Keelung, Taiwan, R.O.C.

\section{INTRODUCTION}

Cobia (Rachycentron canadum) is a medium-sized marine fish and used to be a favorable sport-fishing species [8, 25]. Ever since the artificial propagation through natural spawning in captivity was successfully conducted in 1992, the aquaculture of cobia has been made possible [16-17, 30].

This fish is a fast-growing species and can reach up to $8 \mathrm{~kg}$ within one year from 50 100 $\mathrm{g}$ fingerling in a cage-culturing system [16-17, 34]. Cobia is presently considered as one of the most popular aquaculture species in Taiwan, particularly for off-shore cage culture [17]. Annual production of cultured cobia was around 4,500 mt [9]. In addition to Taiwan, the fish is also cultured in China, Vietnam, Japan, Indonesia, the Americas and the Caribbean [17].

Through the aquaculture involvement, it is expected that the value of cobia is as a new global seafood commodity, might become as equally important as salmon. This new business requires a lot of efforts before a quality product available for seafood consumers around the world. Therefore the engagement in the production of high quality product of cobia is the most important task. Since cobia is considered as a highvalued product, the meat quality of the cultured cobia highly affects the price of it. Very limited literatures were available in this regard; therefore, the objective of this study is to compare the chemical compositions and flavor-related compounds not only between the wild and the cultured cobia but also between two cultured localities in Taiwan. This study is expected to be of academic interest and practical value.

\section{MATERIALS AND METHODS}

\section{Fish}

Nine cobia with the weight ranging from $4,561 \mathrm{~g}$ to $8,780 \mathrm{~g}$ were captured wild along Penghu coast. Nine additional cobia each of the compatible size weighing from $4,691 \mathrm{~g}$ to $8,998 \mathrm{~g}$ were also sampled from two cage-cultured farms of Penghu (PH) County and Pingtung (PT) County, respectively (Table 1). All fish were separately held in cooler filled with sufficient ice immediately after sampling and brought to the laboratory in 
Table 1. Body weight, body length and condition factor of wild and cultured cobia from two localities in Taiwan.

\begin{tabular}{lccc}
\hline & \multirow{2}{*}{ Wild } & \multicolumn{2}{c}{ Cultured } \\
\cline { 3 - 4 } & & Pingtung (PT) & Penghu (PH) \\
\hline Body weight $(\mathrm{g})$ & $7506 \pm 1364^{\mathrm{a} 1}$ & $6304 \pm 1170^{\mathrm{a}}$ & $7039 \pm 1346^{\mathrm{a}}$ \\
& $(4561-8780)^{2}$ & $(4691-8703)$ & $(5010-8998)$ \\
& & & \\
Body length (cm) & $91.80 \pm 5.9^{\mathrm{a}}$ & $79.80 \pm 4.6^{\mathrm{b}}$ & $80.80 \pm 4.7^{\mathrm{b}}$ \\
& $(79.66-97.0)$ & $(74.0-87.0)$ & $(74.0-87.0)$ \\
& & & \\
Condition factor & $9.6 \pm 0.7^{\mathrm{b}}$ & $12.3 \pm 0.9^{\mathrm{a}}$ & $13.3 \pm 1.7^{\mathrm{a}}$ \\
& $(8.6-10.6)$ & $(11.2-13.6)$ & $(10.1-15.8)$ \\
\hline
\end{tabular}

${ }^{1}$ Mean \pm standard deviation $(n=9)$. Mean values within a row not sharing the same superscript were significantly different at $5 \%$ level.

${ }^{2}$ Range of 9 fish.

Keelung. On arrival at the laboratory, they were individually measured the weight and length and stored in deep freezer $\left(-40^{\circ} \mathrm{C}\right)$ until use. After partial thawing, each fish was filleted individually to obtain dorsal and ventral muscles for all chemical analyses. The analyses were done in nine replicates.

\section{Methods}

\section{1) Condition Factor (K)}

It was calculated according to the following formula: $K=$ (body weight in gram/body length ${ }^{3}$ in centimeter) $\times 1000$.

\section{2) $\mathrm{pH}$ Value}

A $5 \mathrm{~g}$ tissue sample was homogenized in $45 \mathrm{ml}$ distilled water and then the $\mathrm{pH}$ value was measured with $\mathrm{pH}$ meter (Schoff C G 840).

\section{3) Proximate Composition}

Moisture, crude protein, crude lipid and ash contents were determined according to the AOAC method [2]. Protein was estimated by total nitrogen multiplied by 6.25 .

\section{4) Free Amino Acids, Dipeptides, Ammonia and Urea}

The extracts of free amino acids (FAAs), dipeptides (anserine, carnosine), ammonia and urea in the dorsal and ventral muscles were prepared according to the method described by Konosu et al. [14]. A $10 \mathrm{~g}$ tissue sample was homogenized for $2 \mathrm{~min}$ in $20 \mathrm{ml}$ of $7 \%$ cold trichloroacetic acid (TCA) using a Polytron homogenizer. The homogenate was centrifuged at $4000 \mathrm{~g}\left(4^{\circ} \mathrm{C}\right)$ for $20 \mathrm{~min}$. The precipitate was extracted twice according to the same procedure. The supernatants were combined and made up to $100 \mathrm{ml}$ with $7 \%$ TCA. A $20 \mathrm{ml} \mathrm{TCA}$ extracted supernatant was mixed with an equal amount of ether to remove the TCA. This procedure was repeated successively five times. The aqueous solution was evaporated to dryness in a vacuum evaporator at a temperature below $40^{\circ} \mathrm{C}$. The dried matter was diluted with distilled water and made up to $25 \mathrm{ml}$ for analyses.

As described in a previous paper [29], FAAs, dipeptides, ammonia and urea were separated by ion exchange chromatography and analyzed by a Hitachi L- 8500 high-speed amino acid analyzer with a Hitachi 2622 SC packed column (4.6 $\mathrm{mm} \times 60 \mathrm{~mm}$ ). The buffers used were the standard lithium citrate buffers. Postcolumn derivatization with ninhydrin yielded amino acid derivatives which were measured by the absorbance at 570 and $440 \mathrm{~nm}$. Analytical conditions and procedures were performed according to the manual provided by the manufacturer (Hitachi, Ltd., Tokyo, Japan). The levels of FAAs, dipeptides, ammonia and urea were estimated on the basis of peak areas of known concentrations of the standards (Wako, Ltd. Osaka, Japan) by using a Hitachi D-2850 chromats data processor.

\section{5) ATP-related Compounds}

The extracts of ATP-related compounds (ARCs) in dorsal and ventral muscles were prepared according to the method of Suwetja et al. [31]. A $5 \mathrm{~g}$ tissue sample was homogenized for $2 \mathrm{~min}$ in $15 \mathrm{ml}$ pre-cooled $6 \%$ perchloric acid (PCA) solution. The homogenate was centrifuged at $1600 \mathrm{~g}\left(4^{\circ} \mathrm{C}\right)$ for $20 \mathrm{~min}$. The supernatant was filtered with Toyo \#2 filter paper and the precipitate was extracted twice with 6\% PCA. The supernatants were combined, adjusted to $\mathrm{pH} 6.5$ with $1 \mathrm{~N} \mathrm{KOH}$ and then incubated for $30 \mathrm{~min}$ at $0^{\circ} \mathrm{C}$ to precipitate potassium perchlorate. After filtration, the supernatant was made up to $100 \mathrm{ml}$ with neutralized PCA solution ( $\mathrm{pH} \mathrm{6.5)}$ for ARCs analyses. ARCs including ATP, ADP, AMP, IMP, inosine (HxR) and hypoxanthin (Hx) were determined by highperformance liquid chromatography (HPLC, Shimadzu LC10A) as described by Shiau et al. [29]. In brief, a $25 \mu$ l portion of the PCA extract, previously filtered through a $0.2 \mu \mathrm{m}$ membrane, was injected into a Cosmosil packed column (4.6 $\mathrm{mm} \times$ $250 \mathrm{~mm}$ ). Two mobile phases used for the separation of ARCs consisted of eluent A, $50 \mathrm{mM} \mathrm{KH} \mathrm{PO}_{4}-\mathrm{K}_{2} \mathrm{HPO}_{4}$ (pH 6.5), and eluent $\mathrm{B}$, a mixture of eluent A solution and methanol (9:1, $\mathrm{v} / \mathrm{v})$. Eluent $\mathrm{A}$ was applied for $14 \mathrm{~min}$, followed by a linear gradient with an increase in eluent B up to $100 \%$ in $11 \mathrm{~min}$ and then by eluent B for $25 \mathrm{~min}$. The flow rate was set to 0.7 $\mathrm{ml} / \mathrm{min}$ and the column temperature was held at $25^{\circ} \mathrm{C}$. The eluent was monitored by UV absorption at $254 \mathrm{~nm}$. The ARCs were identified by comparing the retention times of peaks in HPLC between samples and authentic compounds (Sigma Chemi-cal Co., St. Louis, MD). For quantification, calibration curves were constructed in concentration from 0.05 to 0.8 nmol.

\section{6) Statistical Analysis}

Data were analyzed using analysis of variance (ANOVA) through SAS/PC Program (SAS Institute, Cary, NC). Duncan's multiple-range test was applied to determine the significance of differences between the means. 
Table 2. Proximate composition (\%) of dorsal (D) and ventral (V) muscles of wild and cultured cobia from two localities in Taiwan.

\begin{tabular}{lcccc}
\hline & \multirow{2}{*}{ Wild } & \multicolumn{2}{c}{ Cultured } \\
\cline { 4 - 5 } & & & Pingtung (PT) & Penghu (PH) \\
\hline Moisture & D & $77.14 \pm 1.90^{\mathrm{a}}$ & $73.59 \pm 2.87^{\mathrm{b}}$ & $71.30 \pm 1.37^{\mathrm{c}}$ \\
& $\mathrm{V}$ & $73.33 \pm 3.27^{\mathrm{a}}$ & $66.62 \pm 4.40^{\mathrm{b}}$ & $65.03 \pm 3.44^{\mathrm{b}}$ \\
Crude Fat & $\mathrm{D}$ & $2.64 \pm 1.46^{\mathrm{c}}$ & $5.45 \pm 2.39^{\mathrm{b}}$ & $8.52 \pm 1.93^{\mathrm{a}}$ \\
& $\mathrm{V}$ & $6.66 \pm 3.54^{\mathrm{b}}$ & $13.66 \pm 4.22^{\mathrm{a}}$ & $16.65 \pm 3.51^{\mathrm{a}}$ \\
& & & & \\
Crude protein & $\mathrm{D}$ & $19.21 \pm 1.10^{\mathrm{a}}$ & $20.25 \pm 1.26^{\mathrm{a}}$ & $19.27 \pm 1.82^{\mathrm{a}}$ \\
& $\mathrm{V}$ & $18.80 \pm 0.82^{\mathrm{a}}$ & $18.36 \pm 0.83^{\mathrm{a}}$ & $17.82 \pm 1.22^{\mathrm{a}}$ \\
Ash & & & & \\
& $\mathrm{D}$ & $1.39 \pm 0.11^{\mathrm{a}}$ & $1.46 \pm 0.16^{\mathrm{a}}$ & $1.35 \pm 0.11^{\mathrm{a}}$ \\
& $\mathrm{V}$ & $1.30 \pm 0.10^{\mathrm{a}}$ & $1.26 \pm 0.14^{\mathrm{a}}$ & $1.23 \pm 0.12^{\mathrm{a}}$ \\
\hline
\end{tabular}

${ }^{1}$ Mean \pm standard deviation $(n=9)$. Mean values within a row not sharing the same superscript were significantly different at $5 \%$ level.

\section{RESULTS}

\section{Condition Factor}

The body weight, body length, condition factor and proximate composition of three different groups of cobia (One wild-captured, and two cultured groups, namely PT and PH) were shown in Table 1. There were no significant differences in their body weight among the three groups. The body length of the wild cobia was significantly higher than that of both cultured groups, while the condition factor of the former was significantly lower $(P<0.05)$ than that of the latter two samples.

\section{Proximate Composition}

The means of moisture content of dorsal (D) muscle in the wild-captured, PT-cultured and PH-cultured cobia were 77.14\%, $73.59 \%$ and $71.30 \%$, respectively (Table 2 ). The moisture of wild cobia was significantly higher than that of the cultured ones. Furthermore, moisture in D muscle of PT group was significantly higher than that of $\mathrm{PH}$-cultured group. The means of moisture of ventral $(\mathrm{V})$ muscle in wild, PT and PH cobia were $73.33 \%, 66.62 \%$ and $65.03 \%$, respectively (Table 2). These figures were obviously lower than those of D muscle in the same group. Again, the moisture in the wild fish was significantly higher than that of the two cultured groups; however, there was no significant difference $(P>0.05)$ between the two cultured groups in the $\mathrm{V}$ muscle.

In contrast, the fat contents were inversely lowered as the moisture contents increased among the three groups. The fat contents of D muscle were $2.64 \%, 5.45 \%$ and $8.52 \%$ in wild, PT and PH groups, respectively. The fat in wild cobia was significantly lower than that of cultured ones. The means of fat content of V muscle in wild, PT and PH cobia were 6.66\%, $13.66 \%$ and $16.65 \%$, respectively. These values almost doubled those of the D muscle in the same group (Table 2). The
Table 3. The contents of ammonia $(\mathrm{mg} / 100 \mathrm{~g})$ and urea $(\mathrm{mg} / 100 \mathrm{~g})$ of dorsal (D) and ventral (V) muscles in wild and cultured cobia from two localities in Taiwan.

\begin{tabular}{lcccc}
\hline & \multirow{2}{*}{ Wild } & \multicolumn{2}{c}{ Cultured } \\
\cline { 3 - 5 } & & & Pingtung (PT) & Penghu (PH) \\
\hline $\mathrm{NH}_{3}$ & $\mathrm{D}$ & $7.32 \pm 1.98^{\mathrm{b} 1}$ & $6.83 \pm 2.14^{\mathrm{b}}$ & $9.56 \pm 1.81^{\mathrm{a}}$ \\
& $\mathrm{V}$ & $6.66 \pm 1.84^{\mathrm{b}}$ & $5.76 \pm 1.66^{\mathrm{b}}$ & $8.91 \pm 1.50^{\mathrm{a}}$ \\
\multirow{2}{*}{ Urea } & $\mathrm{D}$ & $5.22 \pm 1.84^{\mathrm{a}}$ & $4.54 \pm 1.09^{\mathrm{a}}$ & $6.09 \pm 2.21^{\mathrm{a}}$ \\
& $\mathrm{V}$ & $5.13 \pm 1.95^{\mathrm{a}}$ & $4.34 \pm 0.71^{\mathrm{a}}$ & $4.99 \pm 2.51^{\mathrm{a}}$ \\
\hline
\end{tabular}

${ }^{1}$ Mean \pm standard deviation $(n=9)$. Mean values within a row not sharing the same superscript were significantly different at $5 \%$ level.

fat in the $\mathrm{V}$ muscle of wild cobia was significantly lower than that of cultured ones, but there was no significant difference between PT and PH groups.

There were no significant differences among the three groups in protein content of the muscles from both $\mathrm{D}$ and $\mathrm{V}$ portions. The relatively narrow ranges of the means of protein level in D and V muscles were 19.21 20.25\% and 17.82 $18.80 \%$, respectively. No significant differences in ash content were found among the three groups, either in $\mathrm{D}$ or $\mathrm{V}$ muscle (Table 2). The ranges of ash level in $\mathrm{D}$ and $\mathrm{V}$ muscles were $1.35 \sim 1.46 \%$ and $1.23 \sim 1.30 \%$, respectively.

\section{Ammonia and Urea}

Results of the determination of ammonia and urea in the D and $\mathrm{V}$ muscles of wild-captured and two cultured groups were shown in Table 3. Ammonia levels of PH-cultured cobia in D and $\mathrm{V}$ muscles were 9.56 and $8.91 \mathrm{mg} / 100 \mathrm{~g}$, respectively, and were significantly higher than those of both wild and PTcultured groups. No significant difference in ammonia levels of D and V muscles was found between wild and PT groups. There was no significant difference of urea level in either D or $\mathrm{V}$ muscle among the three groups.

\section{Free Amino Acids and Dipeptides}

Tables 4 and 5 show the contents of free amino acids (FAAs) and dipeptides (expressed as $\mathrm{mg}$ per $100 \mathrm{~g}$ of wet weight) in D and $\mathrm{V}$ muscles, respectively. The means of total FAAs of $\mathrm{D}$ muscles in wild, PT- and PH-cultured cobia were 123, 196 and $246 \mathrm{mg} / 100 \mathrm{~g}$, respectively. Although there was no significant difference in total FAAs between the D muscle of wild and PT-cultured cobia, the total FAAs in PH-cultured fish was significantly higher than that in the wild-captured one.

Taurine (Tau), glycine (Gly), alanine (Ala) and lysine (Lys) were the major FAAs in D muscle of wild cobia. The level of Tau was the highest among the four major FAAs. The sum of the four FAAs accounted for $63 \%$ of the total FAAs. Tau, glutamic acid (Glu), Gly, Ala, Lys and proline (Pro) were the major FAAs in D muscle of PT-cultured cobia. Gly was the highest among these six FAAs. The sum of the six FAAs accounted for $69 \%$ of total FAAs. Major FAAs in D muscle 
Table 4. Free amino acids and dipeptides $(\mathrm{mg} / 100 \mathrm{~g})$ of dorsal muscles in wild and cultured cobia from different localities in Taiwan.

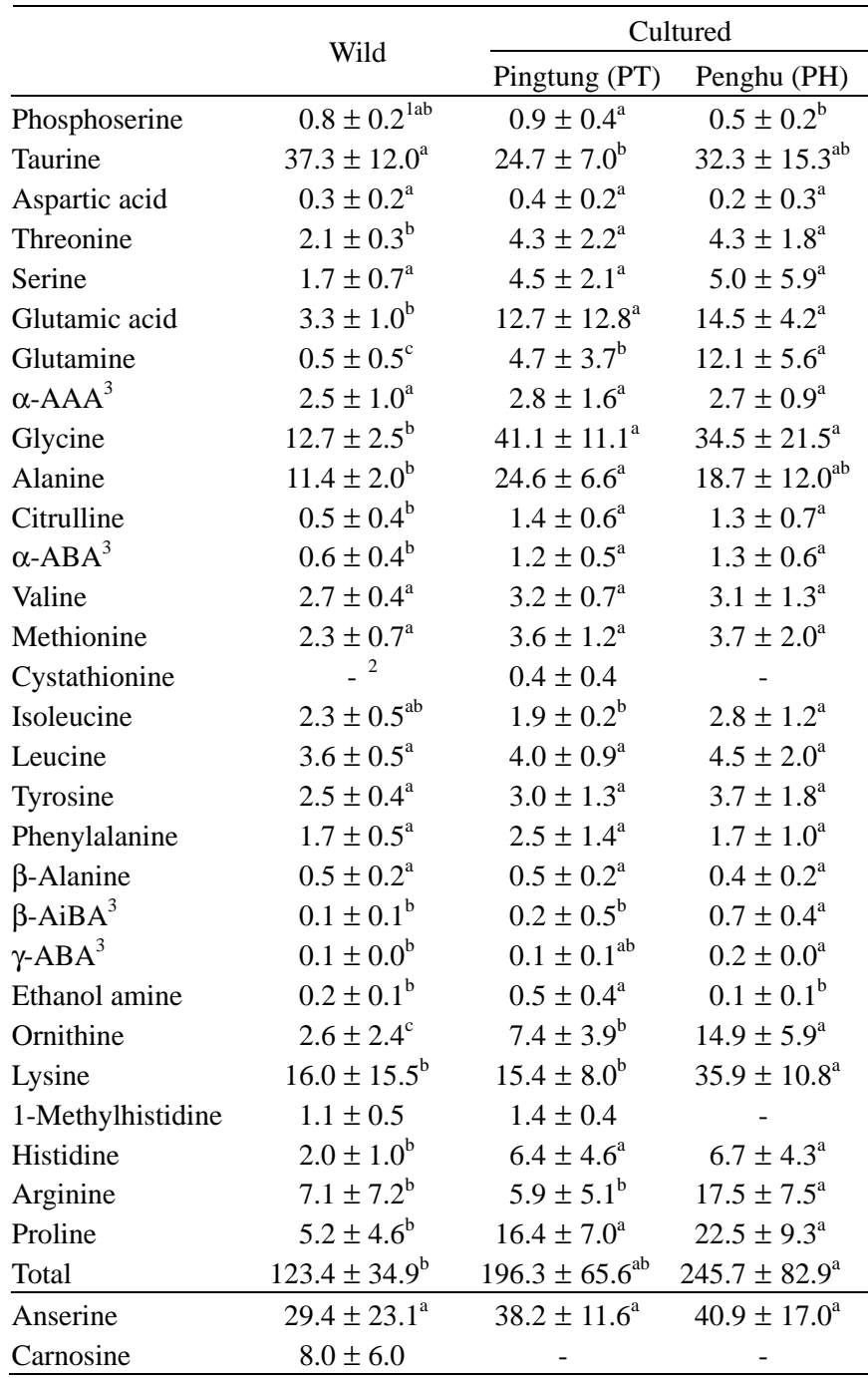

${ }^{1}$ Mean \pm standard deviation $(n=9)$. Mean values within a row not sharing the same superscript were significantly different at $5 \%$ level.

2 -, not detectable.

${ }^{3} \alpha$-AAA, $\alpha$-aminoadipic acid; $\alpha$-ABA, $\alpha$-aminobutyric acid; $\beta$-AiBA, $\beta$-amino-isobutyric acid; $\gamma$-ABA, $\gamma$-aminobutyric acid.

of PH-cultured cobia were Tau, Glu, Glutamine (Gln), Gly, Ala, ornithine (Orn) and arginine (Arg), among which Lys, Gly and Tau were higher in level. The sum of the nine FAAs accounted for $83 \%$ of total FAAs. The level of Tau seemed higher in wild cobia than that of the cultured ones, while the levels of Glu, Gln, Gly, Ala, Orn and Pro in the cultured cobia were significantly higher than those in the wild fish.

The levels of Lys and Arg in PH-cultured cobia were significantly higher than those in both wild and PT-cultured groups. Among the D muscle of the three groups, there was no significant difference in anserine (Ans), one of the dipeptides. Carnosine (Car), another dipeptide, was not detected in
Table 5. Free amino acids and dipeptides $(\mathrm{mg} / 100 \mathrm{~g})$ of ventral muscle in wild and cultured cobia from different localities in Taiwan.

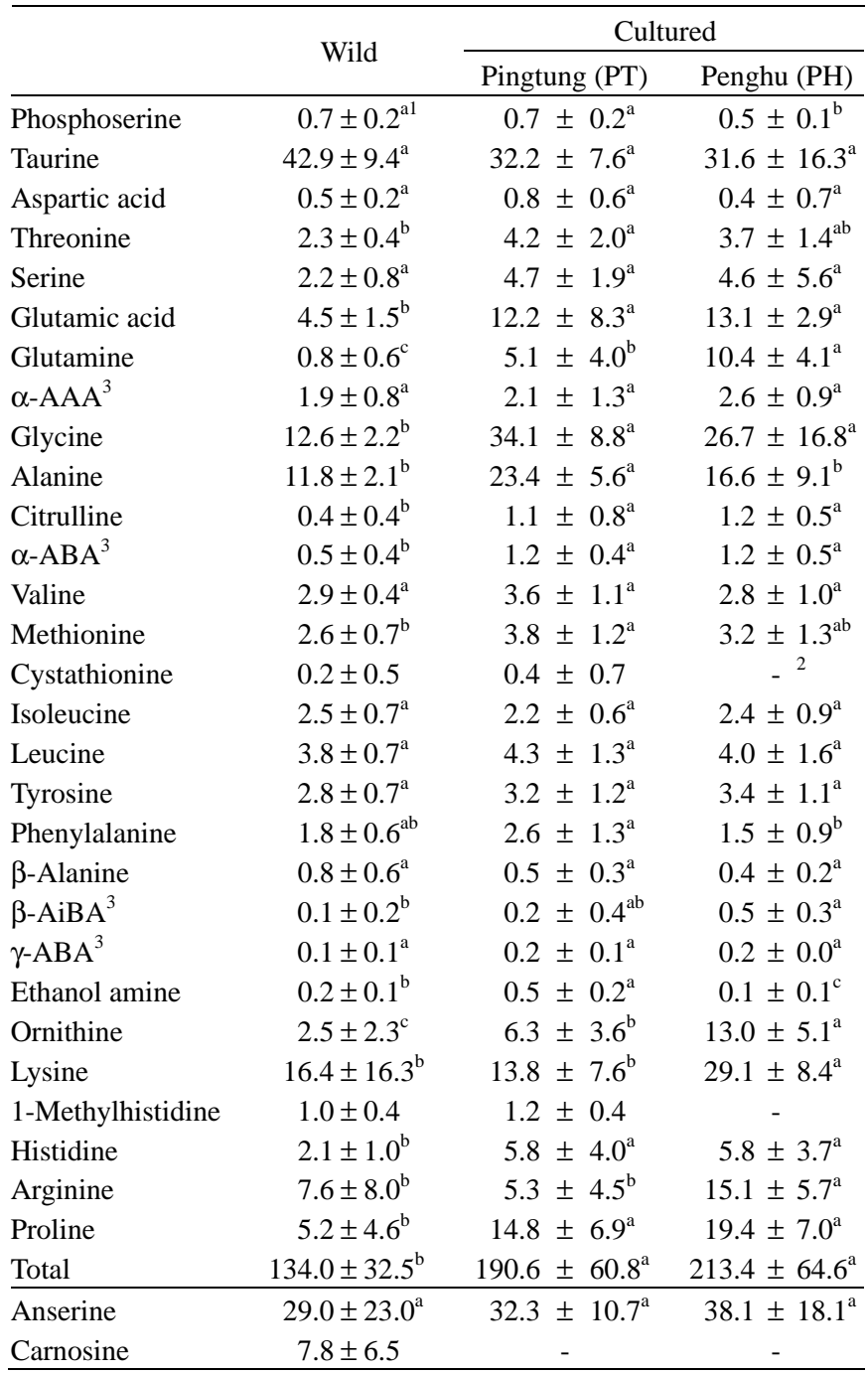

${ }^{1}$ Mean \pm standard deviation $(n=9)$. Mean values within a row not sharing the same superscript were significantly different at $5 \%$ level. 2 -, not detectable.

${ }^{3} \alpha$-AAA, $\alpha$-aminoadipic acid; $\alpha$-ABA, $\alpha$-aminobutyric acid; $\beta$-AiBA, $\beta$-amino-isobutyric acid; $\gamma$-ABA, $\gamma$-aminobutyric acid.

either PT- or PH- cultured cobia. Car was found at a level of $8.0 \mathrm{mg} / 100 \mathrm{mg}$ in D muscle of wild cobia (Table 4).

The means of total FAAs of V muscle in the wild, PT- and PH-cultured cobia were 134, 191 and $213 \mathrm{mg} / 100 \mathrm{~g}$, respectively (Table 5). These figures were similar to those of D muscle in the same group. Again the total FAAs were significantly higher in cultured cobia groups than in wild cobia. As found in the D muscle, Tau, Gly, Ala and Lys were also the four major FAAs in $\mathrm{V}$ muscle of the wild, and were summed up to account for $62 \%$ of total FAAs. Tau was the highest FAA in wild cobia. Gly and Tau were the two highest FAAs found in the V muscle of PT-cultured cobia. Lys and Tau were the two 
Table 6. The ATP-related compounds $(\mu$ mole/g) of dorsal (D) and ventral (V) muscle in wild and cultured cobia from two localities in Taiwan.

\begin{tabular}{lcccc}
\hline & & Wild & \multicolumn{2}{c}{ Cultured } \\
\cline { 4 - 5 } & & & Pingtung (PT) & Penghu (PH) \\
\hline ATP & D & $-^{1}$ & $0.02 \pm 0.02$ & $0.02 \pm 0.03$ \\
& V & - & $0.03 \pm 0.02$ & $0.03 \pm 0.04$ \\
ADP & D & $0.02 \pm 0.04^{\mathrm{b} 2}$ & $0.28 \pm 0.20^{\mathrm{a}}$ & $0.13 \pm 0.04^{\mathrm{b}}$ \\
& $\mathrm{V}$ & $0.04 \pm 0.04^{\mathrm{b}}$ & $0.22 \pm 0.16^{\mathrm{a}}$ & $0.10 \pm 0.05^{\mathrm{b}}$ \\
AMP & $\mathrm{D}$ & $0.50 \pm 0.07^{\mathrm{a}}$ & $0.26 \pm 0.19^{\mathrm{b}}$ & $0.04 \pm 0.10^{\mathrm{c}}$ \\
& $\mathrm{V}$ & $0.45 \pm 0.05^{\mathrm{a}}$ & $0.24 \pm 0.16^{\mathrm{b}}$ & $0.01 \pm 0.01^{\mathrm{c}}$ \\
IMP & $\mathrm{D}$ & $8.50 \pm 1.19^{\mathrm{a}}$ & $7.87 \pm 0.97^{\mathrm{a}}$ & $8.53 \pm 2.48^{\mathrm{a}}$ \\
& $\mathrm{V}$ & $7.41 \pm 1.05^{\mathrm{a}}$ & $5.92 \pm 2.26^{\mathrm{a}}$ & $7.42 \pm 1.60^{\mathrm{a}}$ \\
Inosine & $\mathrm{D}$ & $0.94 \pm 0.21^{\mathrm{a}}$ & $0.87 \pm 0.45^{\mathrm{a}}$ & $0.97 \pm 0.74^{\mathrm{a}}$ \\
& $\mathrm{V}$ & $1.04 \pm 0.18^{\mathrm{a}}$ & $1.15 \pm 0.66^{\mathrm{a}}$ & $0.71 \pm 0.32^{\mathrm{a}}$ \\
Hypoxanthin & $\mathrm{D}$ & $0.38 \pm 0.11^{\mathrm{a}}$ & $0.25 \pm 0.26^{\mathrm{a}}$ & $0.44 \pm 0.43^{\mathrm{a}}$ \\
(HX) & $\mathrm{V}$ & $0.51 \pm 0.17^{\mathrm{a}}$ & $0.65 \pm 0.97^{\mathrm{a}}$ & $0.35 \pm 0.19^{\mathrm{a}}$ \\
\multirow{3}{*}{ Total } & & & & \\
& $\mathrm{D}$ & $10.34 \pm 1.27^{\mathrm{a}}$ & $9.54 \pm 0.89^{\mathrm{a}}$ & $10.11 \pm 2.42^{\mathrm{a}}$ \\
& $\mathrm{V}$ & $9.44 \pm 1.12^{\mathrm{a}}$ & $8.20 \pm 0.89^{\mathrm{b}}$ & $8.61 \pm 1.34^{\mathrm{ab}}$ \\
\hline
\end{tabular}

${ }^{1}$-, not detectable.

${ }^{2}$ Mean \pm standard deviation $(n=9)$. Mean values within a row not sharing the same superscript were significantly different at $5 \%$ level.

highest FAAs in the $\mathrm{V}$ muscle of $\mathrm{PH}$ group.

As compared to wild cobia, the levels of Glu, Gln, Gly, Ala, Orn and Pro were found higher in both cultured groups. Lys and Arg levels of V muscle in PH group were significantly higher than those in PT group. There was no significant difference in Ans between wild and cultured groups. Car which was not found in both cultured groups was found at a mean level of $7.8 \mathrm{mg} / 100 \mathrm{~g}$ in $\mathrm{V}$ muscle of wild cobia (Table 5).

\section{ATP-Related Compounds}

Results of the determination of ATP-related compounds (ARCs) in the $\mathrm{D}$ and $\mathrm{V}$ muscles of wild-captured and two cultured groups were shown in Table 6. There were no significant differences in total ARCs among D muscle of the three groups. The mean values of the three groups ranged from 9.54 to $10.34 \mu \mathrm{mole} / \mathrm{g}$. Inosine monophosphate (IMP) was the most prominent component in ARCs and accounted for $82 \%$ of total ARCs in all D muscles. The total ARCs in V muscle of wild cobia was significant higher than those in $\mathrm{V}$ muscle of PT-cultured group, but had no difference from those of PH-cultured group. IMP was also the most prominent compounds in ARCs, and accounted for over $72 \%$ of the total ARCs in V muscle of the three groups.

\section{DISCUSSION}

It was found in this study that the condition factor of cultured cobia was significantly higher by $28 \sim 38.5 \%$ than that of wild-captured cobia. Similar results have been shown in ayu $[21,32]$ and plaice [11] when cultured and wild-captured ones were compared. Fat contents of fish muscles were usually higher in cultured ones than in wild ones of the same species, while moisture contents tend to be less in the former than in the latter. The results that the fat content in general was affected the moisture and was higher in the cultured ones than in wild ones have also been demonstrated in red sea bream [18, 22], ayu [32], horse mackerel [15], bastard halibut [28], coho salmon [10], red drum [12], Kokanee salmon [23] and plaice [11]. However, Saito and Kunisaki [27] found that there was no significant difference in proximate composition of the muscle between wild and cultured puffer fish.

Saeki and Kumagai [26] compared the chemical composition of ten kinds of cultured fishes with that of their wildcaptured ones and divided them into three categories. Group1 which included grouper, rudder fish and unicorn fish demonstrated that their moisture contents were lower in cultured ones than in wild ones, while fat contents were higher in the former than in the latter. Group 2 which included horse mackerel, black sea bream and rockfish showed that their fat contents were higher in cultured ones than wild ones, but no difference in moisture between cultured and wild ones. Group 3 appeared that there were no differences in proximate composition between wild and cultured ones of the same species. This group included parrot fish, mullet and puffer fish. Cobia seems to belong to the first group that higher fat and lower moisture were found in cultured one as compared to wild-captured one. The reason for this phenomenon was that cultured cobia were fed more food in feed form and converted more extra energy into storage fat in the muscle than wild one which would constantly consumed energy to search for foods in nature. The fat contents of both $\mathrm{D}$ and $\mathrm{V}$ muscles in the two cultured groups were 2 to 3.3 times higher than those in the wild one (Table 2). Additionally, the fat content of PH-cultured cobia was significantly higher than that of the PT-cultured cobia, suggesting that besides the difference in feed composition, the cultured environment which influenced the activity of the fish might be responsible for this. Hence, the effects of feed formulation, aquaculture environment and cultivation methods on the proximate composition of the fish seemed to deserve a further investigation.

Free amino acids profile of the muscles from wild and cultured puffer fish were compared by Saito and Kunisaki [27]. The amounts of extractive nitrogenous constituents in the D and $\mathrm{V}$ muscles of cultured and wild red sea bream were investigated by Morishita et al. [19]. It was shown that total FAAs of the muscles of the two species were higher in wild fishes than in cultured fishes, and Tau was the major FAA in the wild fishes of both species. Although Tau was also found in this study to be the major FAA in wild-captured cobia, the total FAAs were higher in cultured fish than in wild fish. It seemed that cobia had different pattern from the two above- 
mentioned species.

Many studies have demonstrated Car and Ans possessed antioxidant activities and free radical-scavenging functions [3-5, 35] which may contribute to vasodilatory actions [24]. Suyama et al. [32] indicated that Ans content of wild ayu was three times higher than that of cultured one. Differences in localities and culturing methods including feed formulation affected FAAs and dipeptides of cultured fishes [11, 13, 19]. Ioka and Yamanaka [11] showed that Ans was significantly higher in plaice fed dry pellet which contained high Ans than in the fish fed fresh food, moisture pellet or in the wild fish of the same species. However, no difference in Ans level of cobia was found among the three groups in this study. Abe [1] indicated that chinook salmon fed histidine (His) deficient diet resulted in decreased level of Car of the fish body. Car was not detected in cultured cobia in this study. It would be interesting to investigate how His and Ans in feed affect the body levels of the dipeptides in cobia.

IMP was the major compound among ARCs in many species of fishes including red seabream [13], ayu [32], scombroid fishes [20], rainbow trout [33], tilapia [6], milkfish [29] and cobia [7]. IMP was also found to be the most prominent component among ARCs in cobia of the three groups in this study. When comparing the difference of ARCs between wild and cultured ayu, Suyama et al. [32] showed that IMP level was significantly lower in wild ayu than in cultured one, while the sum of inosine and hypoxanthin was significantly higher in wild one than in cultured one. However, cobia did not appear to have the same results as ayu.

Ammonia levels in most fishes very seldom exceeded 20 $\mathrm{mg} / 100 \mathrm{~g}[13,20,32,33]$, while cobia was found to have a lower ammonia level of even less than $10 \mathrm{mg} / 100 \mathrm{~g}$ in this study. The level of urea in the muscle of teleosts was usually below $50 \mathrm{mg} / 100 \mathrm{~g}$, while the mean of urea level ranged from 4.34 to $6.09 \mathrm{mg} / 100 \mathrm{~g}$ in the three groups of cobia in this study. Levels of both ammonia and urea may make cobia a desirable fish for human consumption, especially when serving in raw form as sashimi.

In conclusion, cultured cobia seems to be a better product than wild-captured one, because fat content and total FAAs including favorable flavoring compounds such as Gly, Ala, Lys and Pro were significantly higher in cultured one than those in wild one. It is likely that this fish can be tailored by feed formulation and other culturing methods.

\section{ACKNOWLEDGMENTS}

This work was supported by a grant from Fisheries Administration, Council of Agriculture, Republic of China.

\section{REFERENCES}

1. Abe, H., "Histidine-related dipeptides: distribution, metabolism and physiological function," Biochemistry and Molecular Biology of Fish, Elsevier Science, Amsterdam, pp. 309-333 (1995).
2. AOAC, Official Methods of Analysis, 16th ed., Association of Official Analytical Chemists, Arlington, Virginia (1995).

3. Aruoma, O. I., Laughton, M. J., and Halliwell, B., "Carnosine, homocarnosine and anserine: Could they act as antioxidants in vivo?" Biochemical Journal, Vol. 264, pp. 863-869 (1989).

4. Boldyrev, A. A., Stvolinsky, S. L., Tyulina, O. V., Koshelev, V. B., Hori, N., and Carpenter, D. O., "Biochemical and physiological evidence that carnosine is an endogenous neuroprotector against free radicals," Cell Molecular Neurobiology, Vol. 17, pp. 259-271 (1997).

5. Chan, K. M. and Decker, E. A., "Endogenous skeletal muscle antioxidants," Critical Review of Food Science and Nutrition, Vol. 34, pp. 403426 (1994).

6. Chiou, T. K., Shiau, C. Y., and Chai, T., "Extractive nitrogenous components of cultured milkfish and tilapia," Nippon Suisan Gakkaishi, Vol. 56, pp. 1313-1317 (1990).

7. Chuang, J. L., Lin, R. T., and Shiau, C. Y., "The relationship between chemical compositions and body weight of cultured cobia (Rachycentron canadum) of different growing stages," Journal of the Fisheries Society of Taiwan, Vol. 34, No. 1, pp. 21-30 (2007).

8. Collette, B. B., "Rachycentridae cobias," Identification Guide for Fishery Purposes, The Western Central Pacific, FAO, Rome, p. 2655 (1996).

9. FA, Fisheries Statistical Yearbook Taiwan Area, Fisheries Administration, Council of Agriculture, Taipei, Taiwan (2007).

10. Hata, M., Sato, Y., Yamaguchi, T., Ito, M., and Kuno, Y., "The chemical and amino acid compositions in tissues of cultured and wild coho salmon Oncorhynchus kisutch," Nippon Suisan Gakkaishi, Vol. 54, pp. 1365-1370 (1988).

11. Ioka, H. and Yamanaka, H., "Quality evaluation of the muscle of cultured plaice fed with three different diets," Nippon Suisan Gakkaishi, Vol. 63, pp. 370-377 (1997).

12. Jahncke, M., Hale, M. B., Gooch, J. A., and Hopkins, J. S., "Comparison of pond-raised and wild red drum (Sciaenops ocellatus) with respect to proximate composition, fatty acid profiles, and sensory evaluations," Journal of Food Science, Vol. 53, pp. 286-287 (1988).

13. Konosu, S. and Watanabe, K., "Comparison of nitrogenous extractives of cultured and wild red sea breams," Bulletin of the Japanese Society of Scientific Fisheries, Vol. 42, pp. 1263-1266 (1976).

14. Konosu, S., Watanabe, K., and Shimizu, T., "Distribution of nitrogenous constituents in the muscle extracts of eight species of fish," Bulletin of the Japanese Society of Scientific Fisheries, Vol. 40, pp. 909-915 (1974).

15. Kunisaki, N., Takada, K., and Matsuura, H., "On the study of lipid contents, muscle hardness and fatty acid compositions of wild and cultured horse mackerel," Bulletin of the Japanese Society of Scientific Fisheries, Vol. 52, pp. 333-336 (1986).

16. Liao, I. C., Huang, T. S., Tsai, W. S., Hsueh, C. M., Chang S. L., and Leaño, E. M., "Cobia culture in Taiwan: Current status and problems," Aquaculture, Vol. 237, pp. 155-165 (2004).

17. Liao, I. C. and Leaño, E. M., Cobia Aquaculture: Research, Development and Commercial Production, National Taiwan Ocean University, Keelung, Taiwan (2007).

18. Morishita, T., Uno, K., Araki, T., and Takahashi, T., "Comparison of the fatty acid compositions in cultured red sea bream differing in the localities and culture methods, and those in wild fish," Nippon Suisan Gakkaishi, Vol. 55, pp. 847-852 (1989).

19. Morishita, T., Uno, K., Araki, T., and Takahashi, T., "Comparison of the amounts of extractive nitrogenous constituents in the meats of cultured red sea bream of different localities and culture methods, and those of wild fish," Nippon Suisan Gakkaishi, Vol. 55, pp. 1565-1573 (1989).

20. Murata, Y., Henmi, H., and Nishioka, F., "Extractive components in the skeletal muscle from ten different species of scombroid fishes," Fisheries Science, Vol. 60, pp. 473-478 (1994).

21. Nakagawa, H., Takahara, Y., and Nematipour, G. R., "Comparison of lipid properties between wild and cultured ayu," Nippon Suisan Gakkaishi, Vol. 57, pp. 1965-1971 (1991).

22. Ohshima, T., Wada, S., and Koizumi, C., "Comparison of lipids between cultured and wild sea breams," Bulletin of the Japanese Society of Sci- 
entific Fisheries, Vol. 49, pp. 1405-1409 (1983).

23. Ozawa, A., Satake, M., and Fujita, T., "Comparison of muscle lipids between wild and cultured kokanee salmon," Nippon Suisan Gakkaishi, Vol. 59, pp. 1545-1549 (1993).

24. Ririe, D. G., Roberts, P. K., Shouse, M. N., and Zaloga, G. P., "Vasodilatory actions of the dietary peptide carnosine," Nutrition, Vol. 16, pp. 168$172(2000)$

25. Robins, C. R. and Ray, G. C., A Field Guide to Atlantic Coast Fishes of North America. Houghton Mifflin Co., Boston, p. 354 (1986).

26. Saeki, K. and Kumagai, H., "Chemical components in ten kinds of wild and cultured fishes," Nippon Suisan Gakkaishi, Vol. 50, pp. 1551-1554 (1984).

27. Saito, M. and Kunisaki, N., "Proximate composition, fatty acid composition, free amino acid contents, mineral contents, and hardness of muscle from wild and cultured puffer fish Takifugu rubripes," Nippon Suisan Gakkaishi, Vol. 64, 116-120 (1998).

28. Sato, M., Yoshinaka, R., Nishinaka, Y., Morimoto, H., Kojima, T., Yamamoto, Y., and Ikeda, S., "Comparison of nutritive components in meat of wild and cultured bastard halibut Paralichthys olivaceus," Bulletin of the Japanese Society of Scientific Fisheries, Vol. 52, pp. 1043-1047 (1986).

29. Shiau, C. Y., Pong, Y. J., Chiou, T. K., and Chai, T., "Free amino acids and nucleotide-related compounds in milkfish (Chanos chanos) muscles and viscera," Journal of Agricultural and Food Chemistry, Vol. 44, pp. 26502653 (1996).

30. Su, M. S., Chien, Y. H., and Liao, I. C., "Potential of marine age aquaculture in Taiwan: Cobia culture," Cage Aquaculture in Asia, Asian Fisheries Society, Manila, Philippines and World Aquaculture SocietySoutheast Asian Chapter, Bangkok, Thailand, pp. 97-106 (2000).

31. Suwetja, I. K., Hori, K., and Miyazawa, K., "Changes in content of ATPrelated compounds, homarine and trigonelline in marine invertebrates during ice storage," Nippon Suisan Gakkaishi, Vol. 55, pp. 559-566 (1989).

32. Suyama, M., Hirano, T., Okada, N., and Shibuya, T., "Quality of wild and cultured ayu-I. On the proximate composition, free amino acids and related compounds," Bulletin of the Japanese Society of Scientific Fisheries, Vol. 43, pp. 535-540 (1977)

33. Suzuki, T., Hirano, T., and Shirai, T., "Distribution of extractive nitrogenous constituents in white and dark muscles of fresh-water fish," Comparative Biochemistry and Physiology, Vol. 96B, pp. 107-111 (1990).

34. Tzen, S. C., "Net-cage culture in Taiwan," Fish World, Vol. 8, pp. 14-21 (2000).

35. Wu, H. C., Shiau, C. Y., Chen, H. M., and Chiou, T. K., "Antioxidant activities of carnosine, anserine, some free amino acids and their combination," Journal of Food and Drug Analysis, Vol. 11, pp. 148-153 (2003). 